Roland Bardy and Arthur Rubens:

\title{
A Comparative View of Business Ethics and Governance in the U.S. and Continental Europe
}

\begin{abstract}
:
The paper contrasts the economic, ethical, and organizational differences in the U.S. and Europe, as well as the differences in governance and leadership between U.S. and European managers, and how these differences impact decision-making and governance of U.S. and European businesses. In addition, the paper explores and contrasts select ethical and cultural issues between managers on both sides of the Atlantic. It is the authors' view that on both sides of the Atlantic we embrace the call for more ethics in our lives and we expect it from our business leaders and our business dealings. However, in the markets we consistently have seen a short-term orientation of corporate outcomes. It is hoped that there will be a silver lining to the current economic crisis that will help move us away from this position which makes things like ethics, long-term virtues, fairness, all nice to talk about but somewhat estranged from the realities that are practiced in businesses. It remains to be seen if U.S. organizations, business schools and business leaders will change this current position more rapidly than in Europe. The authors are confident, however, that businesses and governments on both sides of the Atlantic will make all efforts for a pronounced transition to integrate ethics into the real strategic thrusts of conducting business.
\end{abstract}

\section{Agenda}

Introduction .25

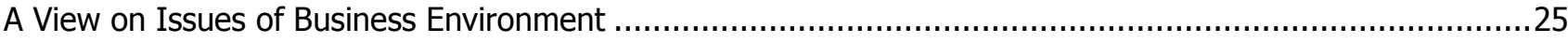

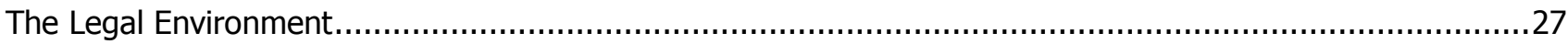

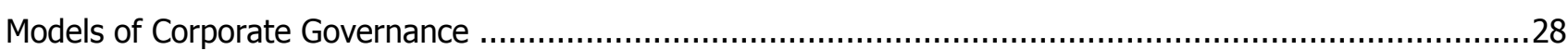

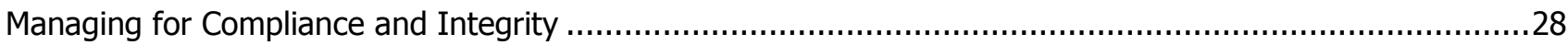

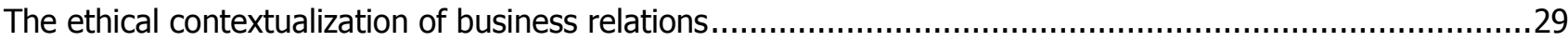

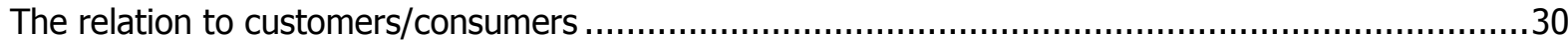

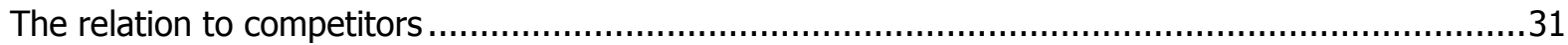

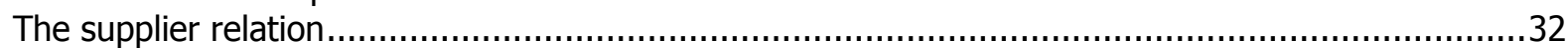

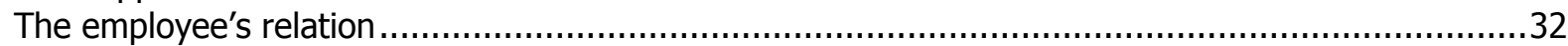

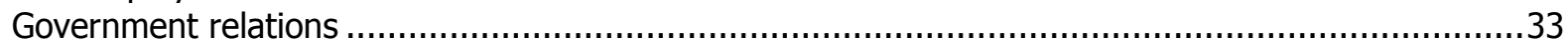

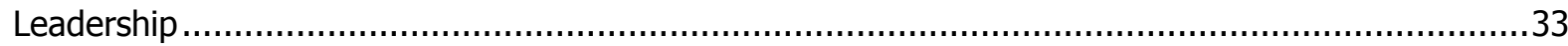

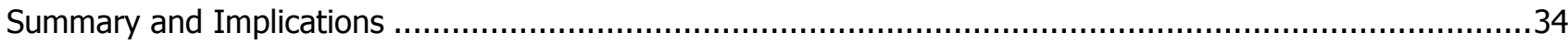

\section{Authors:}

Dr. Roland Bardy:

- Organization and contact address: Adjunct Professor of International Management, Fachhochschule Worms, Germany

- Telephone, email and personal homepage: $₫$ rbardy@t-online.de

- Relevant publications:

Bardy, R., A. Rubens and J. Schoenfeld: „Business Ethics and Legal Environment of Business in the U.S. and in Continental Europe". In: Journal of Business Disciplines, 1527-151-X, Vol 1(2); 2008, pp 1-35. 
Dr. Arthur Rubens:

- Organization and contact address: Associate Professor of Management, Florida Gulf Coast University, Fort Myers, FL

- $\bowtie$ arubens@fgcu.edu 


\section{Introduction}

Historically there has been a history of pronounced divide of governance and legal systems between the Nordic states and the United Kingdom on the one end and Continental Europe on the other end. The US approach has been nourished mainly from the U.K.; however, contrasting views on how corporations should be managed and overseen have evolved. These differences greatly effect how CEOs look at issues such as governance, accountability, and strategic decision-making, as well as a host of corporate and ethical issues ranging from CEO compensation to how the CEO and the companies deal with competitive intelligence, intellectual property rights, employee privacy, and customer relations.

Recent events such as the meltdown of our financial markets, corporate bailouts, as well as the infamous corporate scandals such as the Enron catastrophe, the corruptions at WorldCom, Tyco, Vivendi, and Royal Ahold, as well as the passage by U.S. Congress of the Corporate and Auditing Accountability, Responsibility, and Transparency Act of $2002^{47}$ have all served to radically change public and business expectations of corporate accountability. They have brought issues such as business ethics, corporate governance and CEO compensation to the forefront of the business and political agenda ${ }^{48} 4950$. Increasingly, the ethics and decision-making practices of CEOs in the U.S. and Europe are coming under greater scrutiny as more and more CEOs are accused of corporate wrongdoings, and as our businesses and organizations on both sides of the Atlantic are faced with stiff competition from a global market and are required to do more for their customers with fewer resources. In addition, this recent turmoil in the world financial markets has only resulted in solidifying public opinion of the need for change in our corporate boardrooms and how CEOs are to govern. The U.S. and European CEOs in the future are faced with a very different business environment than CEOs of only a few years ago. Issues such as volatile economic and social systems, changing expectations of employees and consumers, cost-containment pressures, and the growing do-

\footnotetext{
${ }^{47}$ Sarbanes-Oxley 2002

${ }^{48}$ Vershoor 2006

${ }^{49}$ Hasson 2002

${ }^{50}$ Roberts 2002
}

minance of China and Asia confront the new managers in the U.S. and Europe and challenge his or her decision-making ability to make equitable and fair decisions, and how to survive in the future. From there, it is hoped that dealing with all these issues will become more ethical. But it is assumed that the differences among Western countries in ethical practices and ideology will remain and will produce different outcomes.

\section{A View on Issues of Business Environment}

The focus and the challenges of business ethics in Continental Europe today must be viewed from the perspective that has evolved after the breakdown of communism. Democracy is new in many countries of Europe, and even though the concept of democracy is European as it was invented in the city state of Athens some 2500 years ago, there is a much longer tradition of democratic values in the U.S., and the types of constitutional set-ups which prevailed in Europe and which have helped to form the business environment are very different from what we have in the U.S.

Exhibit 1 shows a list of where business issues differ between the U.S. and Continental Europe. Foremost is public administration. With regard to how far public administration stretches here and there, one statistic "shows it all": According to an Organization for Economic Co-Operation and Development (OECD) source, total cost of government as a percentage of GDP were: In the US 33.5, in the UK 55.9 , in Germany 55.7, in Italy 59.3, in France 54.0, in Sweden 66.7; the EU average was 51.0. This overall difference explains why the legal environment of business must be different. Also, where we have uniformity in the issue we might still find differences in attitude. For example with the issue of human rights, as long as there was Apartheid in South Africa, US firms withdrew, European firms remained. While there are still US-sanctions against Cuba, EU politicians favor "humanitarian aid," and while the US generally prefers a "hard diplomacy", Europe deploys a much softer and very different type of diplomacy. Yet there is a common base for both, and one may trace it back to Adam Smith who, long before publishing "Wealth of Nations", delineating the goals attained by the homo oeconomicus, wrote "The Theory of Moral Sentiments" where he depicted the homo moralis. One may hold that there is a transatlantic divide in determining which is the proper balance of the two attainments, 
but there will always be an agreement on what

extent this balancing is acceptable.

Exhibit 1 Issues that Demonstrate Differences/Uniformity of Business Ethics in US and Europe:

\begin{tabular}{|l|l|}
\hline Differences & Uniformity \\
\hline Focus of Public Administration & Human Rights \\
\hline System and Curriculums of Education & Free Market \\
\hline Sensitiveness to Stock Price-Effects & Deregulation \\
\hline Corporate Governance & Child Labor \\
\hline Legal System & OECD Code for Multinationals \\
\hline Labor Law & WTO (GATT) TPS \\
\hline Consumer Protection & GATS \\
\hline Privacy Protection & TRIPS \\
\hline Workplace Protection & Sustainable Development \\
\hline Job Rotation & Responsible Care \\
\hline Organizational Transformation (M\&A, Spin-Offs) & Bribery \\
\hline GAAP: Rules-Based; IAS: Principles-Based & Insider Trading \\
\hline Energy Consumption & Trust within Business Relations \\
\hline
\end{tabular}

There are three other, more practical, consequences which may be gleaned from the contents of Exhibit 1: First, from the outward evidence for a preference of rules-based approaches in the U.S. (over the principles-based approaches in Continental Europe) as in matters like GAAP and, more generally, Corporate Governance, we may infer that this has a foundation in ethical approaches which are slightly more instrumental and rules-based in the $\mathrm{US}^{51}$. Secondly, as trust is a common denominator on both sides of the Atlantic with slight variances within Continental Europe ${ }^{52}$, legal barriers to the global

${ }^{51}$ Gibson 2007, Ferrell et. al., 2006

${ }^{52}$ According to the prominent American philosopher Yoshihiro Francis Fukuyama (The End of History 
knowledge economy are bound to fail and even the Commission of the European Union will eventually ease its prohibitive Privacy Rules ${ }^{53}$. And thirdly, as legal provisions have a much wider reach in Continental Europe, e.g. in Labor Law, the spectrum of guidance in the US will more often mix ethical and legal compliance.

\section{The Legal Environment}

Law is inherent in ethics and in how businesses operate. A basic difference between US/Anglo-Saxon and Continental European practice is that the US and the UK apply case law; while on the continent we have a dominance of code law. Then, there is the judiciary: One topic of almost antagonistic layout is that of the competencies of courts. Courts have ample jurisdiction in the U.S., while in continental Europe there is a variety of special courts apart from the ordinary courts such as the labor courts, social courts, and administrative courts. A related topic is that U.S. standing rules allow greater access. For example, in Europe, a case will only be accepted by a court if there is an 'individualized impact', while a case will "stand" before a US- court if whatever infringement of law can be demonstrated. So, while suits to compel administrative action are a normal procedure in the US, in (Continental) Europe cases of administrative inaction are taken to court less frequently than in the US. The Europeans, generally, give priority to a stable political consensus on regulatory matters by prior consultation. In addition, in Europe there are many patterns of tightly knit statesociety-relations and the state organizes social interests into large representative hierarchies. This is often called a "corporatist" environment, and it relates to another issue, i.e. that of employee representation and co-determination: Union laws in the

and the Last Man 1992), the US, Germany and Japan are 'high-trust' societies, while Italy, France, Korea, Taiwan are 'low-trust' societies. He has tested his thesis, and while his findings are that spontaneous sociability - one element of trust makes for economic growth as it establishes orderly industrial structure, he attributes a higher grade to cognitive trust. Cognitive trust is inherent in network organizations and this will give a natural advantage to those societies that have a high degree of trust (Fukuyama 1995). In this, we have what we might call a "partial divide" throughout Europe.

${ }^{53}$ Di Norcia 2002
US are not as compelling as in Europe. Even if this may probably change under the new democratic administration and the democratic congress from 2009, the change will never reach as far as, e.g., labor law in Germany, where co-determination is not only executed on the shop floor level but also in the boards, where trade unions and employees representatives have voting rights. This explains why there will always remain fundamental differences in how corporate governance is organized and practiced.

The legal environment in the former communist states of Central and Eastern Europe (CEE) is still to be developed further. But what matters more is that an underlying ethical foundation like Immanuel Kant's (1724-1804) Categorical Imperative ("Act only on that maxim by which you can at the same time will that it should become a universal law') would be implanted in the CEE states. This would also encompass the fundamentals of what Karl Popper (1902 - 1994) called the "Open Society" and what F.A. Von Hayek (1899 - 1992) called the "abstract rules" of "Just Conduct" (i.e. honoring property rights and contracts). In practice, however, there is not enough emphasis on ethical issues in the process of what the politicians call "homogenizing the rules throughout the EU". For the time being, however, more emphasis is placed on reforming the business laws, on introducing all facets of capital-market-constitution and non-intervention. It seems that the task of dispersing knowledge on "western" business procedures and (ethical) responsibilities is much more taken up by U.S. businesses and U.S. business schools ${ }^{54}$. From that side of the Atlantic also comes the ethical concern of John Rawls (A Theory of Justice - The Ethics of Distribution; 1973): Welfare of mankind still requires control through a set of (fair) rules. Welfare can only be distributed justly if a society, by such fair rules, minimizes the effects of its member's accidental circumstances (intelligence, physical strength, social status). Rawls' ideas may seem to be a representation into the legal of what was expressed philosophically by Jeremy Bentham (1748-1832), the English father of Utilitarianism ("...an action is good if it produces ... the greatest amount of satisfaction for the greatest number of stakeholders affected by the action"). But welfare, according to Rawls, is not just benefits, it is about "primary social goods", which includes the notion that justice (fairness) and selfrespect are prior to questions of mere satisfaction. This certainly is a fundamental ethical principle to be

\footnotetext{
${ }^{54}$ Melloan 2005
} 
divulged in the new CEE democracies, because if any pluralistic community reaches consensus on this, it will achieve political accord.

\section{Models of Corporate Governance}

The main differences between the US and the continental European models of corporate governance are shown in Exhibit 2:

\section{Exhibit 2 Models of Corporate Governance}

\begin{tabular}{|l|l|l|}
\hline Traditional & Co-determination & Stakeholders Model \\
\hline Stockholders & Capital and Labor & Social/political/economic interests \\
\hline Board of Directors & Supervisory Board & Stakeholders in Board \\
\hline Managers & Management Board & Managers \\
\hline Employees & Mgrs/Employees & Employees \\
\hline
\end{tabular}

While the traditional US model of corporate governance features a "one-tier" structure (there is one layer of supervision between stockholders and managers, and this is the board of directors), the continental model of co-determination has two tiers; a supervisory board and a management board, with capital (shareholders), and labor (unions and employees being represented equally in the supervisory board). Some economies in Eastern Europe have set up what is commonly referred to as a "Stakeholder Model"which is also practiced in Northern Europe. It includes social, political and economic interests in the oversight and in the board levels.

There are advantages and disadvantages in both structural layouts of corporate governance. But on both sides of the Atlantic, the ethical dimension remains the same: Accountability is foremost, and "Corporate Citizenship", as well as "Corporate Social Responsibility", though first coined by US corporations, have soon become a commitment in Europe. Going even further, some European countries, e.g. Italy and Austria, have copied the US model of sanctioning corporate crime ${ }^{55}$ by establishing ambitious legal frameworks for corporate criminal re-

55 The US Federal Sanctioning Guidelines of 1991, apart from setting rules for federal judges, have also spurred the divulgement of corporate guidelines and standards on compliance, both legal and ethical sponsibility $^{56}$. Also, the systems and procedures for internal control, compliance and risk management have become universal with global application of the COSO model $(\mathrm{COSO}=$ Committee of Sponsoring Organizations of the Treadway Commission on Corporate Governance) and of GRC Software (GRC = Governance, Risk Management and Compliance). It is self-evident that risk management entails an ethical dimension, because if a business avoids unacceptable and worrying risks it also acts responsibly towards all stakeholders.

\section{Managing for Compliance and Integrity}

Being accountable and being responsible implies that officers on all levels of the corporation are not only able to account but also required to render accounts. In this sense, accountability is part of the normative social order of any community or institution. Corporate governance must provide an appropriate framework of reporting routines, systematic assessment and approval procedures etc., and the moral significance of accounting practice must be upheld and regained, not least because of the prominent role that accounting representations have played in recent corporate scandals. Beyond man-

\footnotetext{
${ }^{56}$ Hefendehl 2001
} 
agement accounting, financial accounting and financial auditing (where substantial reforms are under way with the Sarbanes-Oxley Act and with the 8th European Directive that governs the audit profession), reporting and auditing on ethical and social issues is becoming mandatory in the global environment. One background is the negative attention attracted through consumers, media and non-governmental organizations on, e.g. apparel distributors such as Nike, Levi Strauss, Benetton,

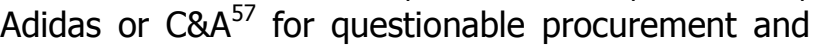
production practices. Another background is the efforts of innumerous institutions establishing internationally accepted standards such as SA 8000, AA 1000 and the Global Reporting Initiative (GRI):

- SA $8000^{58}$ was founded in 1997 and is now under the control of Social Accountability International $(\mathrm{SAI})^{59}$. It is a global, verifiable standard for managing, auditing and certifying compliance with workplace issues, and companies may seek certification through an accredited authorization auditor.

- AA $1000^{60}$ was created by the Institute for Social and Ethical AccountAbility ${ }^{61}$ and its main goal is a so-called "stakeholder engagement". The engagement of stakeholders enables AA 1000 to build confidence and give legitimacy for a good reputation by projecting a defined stance on social and ethical issues.

- GRI is a multi-stakeholder governed institution providing global standards in sustainability reporting and special alignment with the UN Global Compact Principles on Human Rights, Community Impact, Climate Change etc. ${ }^{62}$.

The three sets of standards are very different in their respective inherent logic, and adherence to either SA 8000 or AA 1000 largely depends on the willingness to participate in the audit and certification processes. Information on SA 8000 and $A A$ 1000 compliance is not available publicly. However,

\footnotetext{
${ }^{57}$ Preuss 2001

${ }^{58}$ SAI (Social Accountability International) 2002

${ }^{59}$ www. accountability.org.uk

${ }^{60}$ AccountAbility 1000

${ }^{61}$ Ibid.

${ }^{62}$ www.globalreporting.org
}

GRI is linked to the Corporate Register Database ${ }^{63}$, which can be freely accessed and which as today provides 18880 Corporate Social Responsibility reports across 4779 companies.

The evolution of the standards, especially SA 8000 , may serve to demonstrate that norms will only be generally accepted if all affected stakeholders were involved in their elaboration through the SAI initiative. There is a close link in this to Discourse Ethics which stipulates that "a norm is valid when its foreseeable consequences ... could be jointly accepted by all concerned without coercion", and that "only those norms can claim validity that could meet with the acceptance of all concerned in practical discourse ${ }^{\prime \prime 64}$. Even though it may be argued that not each and every of all potential stakeholders were involved in the making of SA 8000, SAI's intention clearly is to include all argumentation. The ongoing process of SA 8000 amendments will also improve the formal design of dialogues (SA 8000 explicitly asks for stakeholder discourses). And it could further shift the idea of the goal of communication from the result, as in traditional discourse theory (a German feature), to the process itself (an American feature), promoting the concept of an ongoing moral conversation. This difference (another "transatlantic divide") is not just limited to the procedures of the discourse; the US-based philosopher Seyla Benhabib also criticizes that, traditionally, contemporary moral and political theory makes a sharp distinction between matters of justice and matters of the good life, and that it only places the former in the realm of ethics. Her expansion of the traditional idea has led to the inclusion of questions and experiences belonging to the private sphere into the moral and political domain - a development that will definitely promote the range of social accounting ${ }^{65}$.

\section{The ethical contextualization of business relations}

The focus on Corporate Governance is primordial, because oversee, governance and culture influence decision making on all levels. Towards the outside of the corporation, ethical or non-ethical behavior becomes manifest in the contexts of business relations: How does the corporation, how do their

\footnotetext{
${ }^{63}$ www.corporateregister.com

${ }^{64}$ Habermas 1999

${ }^{65}$ Benhabib 2004
} 
officers treat its constituencies (or "stakeholders") customers, consumers, suppliers and service partners, its contractors and employees? And are there differences in this between the US and Europe? Does it matter that the central emphasis on ethics subjects tends to be individual actors in the US, whereas in Europe there is a more "pluralistic" view and hence more interest in institutions? ${ }^{66}$ The main issues will be contextualized as follows:

\section{The relation to customers/consumers}

All links and activities between buyers and vendors are configured through responsibilities that are based on generally accepted values: Autonomy, Freedom, Justice, Trust, Truth and Well-Being are constitutive of a marketing ethics ${ }^{67}$. They are not unique to marketing, because they also relate to other areas of life. But when used in marketing, they are part and parcel of decisions regarding product development, advertising, market research etc. Advertising and its use of "sex and fear" and of deceptive practices is, of course, a favorite target of moral criticism on both sides of the Atlantic. But the practices differ: In the US, comparative advertising is legal, which it is not in the European Union, whilst the tactic of "bait and switch" (making people believe that a certain product is available and then offer them another, more expensive alternative) is illegal in the US, but it is not prohibited by law in Europe. Deceptive pricing by "no frills airlines" has been criticized by advertising watchdogs all along, but an EU regulation came up only recently. This is also due to data problems and the lack of Europeanwide information systems in this area. Nongovernmental initiatives use much more information economics here. An US example is "Consumer Fraud Reporting", an online service that warns consumers about specific types of financial scams via the internet $^{68}$.

In the US as well as in Europe, the legal framework on pricing and market exchange was largely predicated on the notion of "caveat emptor", or buyer beware, even though the historic foundation of "fair dealing" in the US stems from the "Federal Trade Commission Act" which was created in 1914. From there, protection of consumer rights which erodes the notion of "buyer beware" developed much faster

${ }^{66}$ Crane, Matter 2004

67 Brenkert 2008

${ }^{68}$ www.consumerfraudreporting.org in the US (e.g. with the 1975 Consumer Goods Pricing Act) than in Europe. EU regulations as well as national legal frameworks which enshrine the right to safe and efficacious products and to truthful measurements and labeling are worded in very general terms and national laws in Europe differ substantially from each other. So, business ethics very often must begin where the law ends. But there will always be gray areas; if we take the example of "healthy food" and "effectual cosmetics", we are very clearly into consumer vulnerability, and this is where the principles of Trust, Truth and WellBeing should govern. As of 2004, the American Marketing Association (AMA) has adopted a "Statement of Ethical Norms and Values for Marketers" which states those and other principles ${ }^{69}$. Similarly, the European Marketing Confederation (EMC) has issued a Code of Conduct $^{70}$. They might work, because both of them expulse individuals who are found not to have abided by the code - a type of sanction which may be deemed to be severe. Again, in the US, severe punishment is much more drastic than in Europe when consumer fraud is taken to court: Applying the 1991 US Federal Sentencing Guidelines, Acme Corporation was sentenced by US court to pay a fine of four times the loss suffered by its customers who were systematically overcharged for damages occurred during the rent of automobiles $^{71}$.

A field where a Code of Conduct is successfully employed is market research. The Code of the Market Research Society (MRS), with members in more than 70 countries, is intended to reassure the general public and other interested parties that research is carried out in a professional and ethical manner ${ }^{72}$. But here, again, we might find a transatlantic divide: When it comes to covert research, especially in engaged public observation where a researcher talks to people without revealing who she or he is, the US attitude towards privacy protection makes it more likely for this method to be applied. The method is deemed to be justifiable if it does not produce "unnecessary harm to subjects"73. A case that has made history is that of Toyota in its early US campaigns, when the company used its

\footnotetext{
${ }^{69}$ AMA 2004

70 EMC (European Marketing ConfederationEMC) 2005

${ }^{71}$ HBR 2003

${ }^{72}$ MRS (Market Research Society) Code of Conduct

${ }^{73}$ Denzin and Erikson 1982
} 
employees to make friends with potential buyers to learn about their attitudes and preferences.

Market research has received new inputs through web-based data collection: Some argue that the explosion in communications technologies has created an ethical minefield for individuals and companies $^{74}$. Surely the technology allows the individual to become "invisible" on the Web, or to misuse e-mail and Web-surfing or to illegally copy software, and there is the big question what corporations should do about these abuses all over the world (the answer would be a "matter of degree"). But when it comes to abuses produced by businesses, there is a clear divide on what is "material": The EU Directive on Data Protection limits the secondary use of personal information collected from consumers to a very great extent. By contrast, the US is leaning towards industry self-regulation. Europe may pay a heavy fine for its obsession with privacy. Already severely behind in technology, further restrictions on the growth of the Internet may see technological companies bypass European venues.

\section{The relation to competitors}

There is a wide continuum between conflict and collaboration in competitive behavior. Marketing can be seen "as a game, as a war or a social practice"75, and ethical issues in dealing with competitors can either relate to aggressiveness or to elimination of the competitive market. Overly aggressive competition will lead to questionable tactics in intelligence gathering, from the clearly illegal patterns of espionage to the more subtle ways of spying. Beyond the competitive intelligence issues, overly aggressive may apply "dirty tricks" that include negative advertising, stealing customers, predatory pricing and even sabotage. In the US, it was only recently that a case has surfaced which involved Coca-Cola employees who tried to sell the Coke formula to Pepsi Cola $^{76}$. But there were much more cases which became known in Europe: Allegations of industrial espionage were versed against Procter \& Gamble in 2001. The company had hired private investigators to find out more about Unilever's hair care business ${ }^{77}$. Canal Plus, an encryption service company of the French media conglomerate Vivid, claimed that
NDS, a UK-based technology firm $80 \%$ owned by Rupert Murdoch's News Corporation, had deliberately cracked their security technology, and then it had sent it to hackers in the USA ${ }^{78}$.

Aggressive behavior would also encompass illegal copying of intellectual property rights (IPR). Again, the likelihood of a universal codification of IPR protection is poor (as was shown for privacy protection), because there are different traditions: In Continental Europe, the moral rights of authors are emphasized. The Anglo-American tradition emphasizes economic rights, and the Asian tradition considers copying as a matter of emulation of the master. Still, the WTO's Agreement on TradeRelated Aspects of Intellectual Property Rights (TRIPS) is a very powerful instrument, but it refers to inter-governmental relations. At least it enables IPR-owners to take action: Microsoft recently reported a major Egyptian IT company to the local Department of Investigation and Protection of Intellectual Property Rights, a task force run by the Ministry of Interior. The company, which has its headquarters in Nasr City, has been working against the law by installing counterfeit Microsoft Windows and Microsoft Office on the computers it sells.

The opposite of aggressive competition is collusion and cartels. And once more, it seems that the long history of Antitrust law in the US (the Sherman Antitrust Act came into force in 1890) prevents US managers from price fixing through multi-firm conduct and concerted action. US courts see multifirm conduct to have an unambiguously negative effect and judge it more sternly, while the disposition in Europe may be termed to more repugnant to the abuse of a dominant position. E.g., the European Commission is incessantly investigating into Microsoft's bundling of its Media Player software with Windows, while the claim that the big four mobile phone companies were overcharging consumers in the UK has not yet been taken up by the UK Competition Commission. And back in 1999, the world's three biggest vitamin makers, German BASF, Swiss Roche and French Rhône-Poulenc were charged by the US Justice Department for engaging in a massive price-fixing conspiracy long before the European courts took up the matter.

\footnotetext{
${ }^{74}$ Mitchell 2003

${ }^{75}$ Kotler 2000

${ }^{76}$ www.boingboing.net/2006/07/05

77 Financial Times, 31. Aug. 2001
}

${ }^{78}$ The Independent, 1. Oct. 2002 


\section{The supplier relation}

Ethical issues in dealing with suppliers arise on the organizational level (misuse of market power, unfair treatment, unfair advantage) and on the individual level (giving and acceptance of gifts, bribes, hospitality and other inducements). With regard to the organizational, industry seems to move away from the traditional adversarial relationship with its vendors, due in part to the influence of Japanese business where partnership-based approaches prevail. But in retail, unfair treatment happens more often than not: In the highly competitive German foods market, the market leader ALDI earned a very negative reputation when it used its market power in 2007/8 to force milk-producers into accepting a heavy price decrease. Similarly, the British high street retailer Marks \& Spencer suddenly dropped one of its long-term UK clothing suppliers, William Baird textiles group, in 1999, thereby ending a thirty-year business relationship. Baird had to close sixteen factories and lay off 4500 workers $^{79}$. Suppliers should legitimately be able to expect loyalty the specific dealings will have to show what an obligation of loyalty really has to entail.

An issue which pertains to the purchase function but which entails the entire corporation is "Green Procurement", i.e. the selection of products and services that minimize environmental impacts. Other than in Europe, where only a few industries like the chemical and textile businesses perform "sustainable purchase", US buyers, at government institutions and private enterprises, have developed a reputable record in this field across all industries. An example is IBM, which has converted the need to comply with dozens of environmental regulations into a forward strategy. IBM's "Green Strategy" is proactive in limiting the materials it uses in its electronics, and from there it provides environmentally conscious products to its customers, "not from an altruistic standpoint but from a dollars and cents standpoint", because the customers' purchase agents prefer "green products", to ${ }^{80}$.

On the individual level, the topic is not just gifts, gratuities, bribes, kickbacks bungs, sweeteners etc., but also business-supplier negotiation. An ethical approach to negotiation should steer clear of tactics like puffery, weakening the opponent, nondisclosure, distraction and the like. This is not only because it is the right thing to do but also because such practices can incur costs for the negotiator (costs of rigidity, of lost opportunities, etc.). In all, unethical decision making in this context can very well be limited by limiting opportunities. Opportunities arise from conditions that either provide rewards for or fail to erect barriers against unethical behavior. Opportunity also comes from knowledge: Withholding information or lying to vendors (as well as to customers or employees) is the most common type of misconduct observed in the National Business Ethics Survey (NBES) conducted in the US ${ }^{81}$. One remedy lies with information economics: reporting on negotiations, tracing the access to and the use (and misuse) of data will provide solution, as will proper training and socializing newer employees to abide by the rules and norms and the culture of the organization.

\section{The employee's relation}

As mentioned before, the participation of employees and their representatives in corporate decisionmaking is a much wider in Europe than in the US. Apart from the legal background, this is based on the European attitude of decision-making by consensus, and, therefore, employees' rights and duties may be interpreted somewhat differently in the US and in Europe. While the basic rights to freedom from discrimination, to fair wages, to healthy and safe working conditions etc. will be applied similarly, the rights to privacy and to due process (promotion, firing, disciplinary proceedings) are more limited in the US as compared to Europe. This has a downside: Performance monitoring in German corporations often is viewed as "spying on the employees", and one big retailer was recently taken to court on this matter (there was a recent case in German which involved retail giant LIDL). Likewise, codetermination on the board level mixes employee duties (complying with labor contract, respecting the employers' property and values) with the duties, which a board member, who represents a trade union, feels towards this union. In consequence, the other board members might deem it necessary to find out if such an attitude provokes the breach of secrecy. Deutsche Telekom did not see another way out from this dilemma than "spying on employees ${ }^{\prime \prime 2}$.

\footnotetext{
${ }^{81}$ The Ethics Resource Center 2000

${ }^{82}$ www.unwiredview.com, 2008/05/26

${ }^{79}$ The Daily Telegraph, 02. Aug. 2001

${ }^{80}$ IBM (ww.ibm.com): „Big Blue Goes Green”
} 
Spying on employees was also what Boeing meant to be the ultimate resort in November 2007 after a whistleblower was charged with 16 counts of computer trespass for allegedly stealing 320,000 company files and giving some of them to the Seattle Times to document flaws in the company's inspection process for one of its new planes. The company estimated that the stolen data could have cost the company between $\$ 5$ billion and $\$ 15$ billion if the information got into the wrong hands. Boeing set out to restore security to ferret out that type of "whistleblowers" by videotaping workers and reading their e-mail ${ }^{83}$. On the other end, when employees raise concerns about work-related issues that are not taken up adequately, they face a plight: Should they "loyally" accept the situation, or should they blow the whistle? The vast majority of whistleblowing cases are resolved within the chain of command and with the help of human resource management officers ${ }^{84}$. Going to the board or outside the company would only be the last step, but it must be looked at as a part of the system, because "democratic capitalism requires that people trust in the integrity of public and private institutions alike $^{\prime \prime 85}$.

\section{Government relations}

Government has a relation with business where both partners are mutually dependent on each other. For government, the main ethical issue here lies in the necessity of carrying out the mandate it has been given by society, and of course one aspect of this is its constraint and enabling of business. And business is entitled to rely on agreements and guarantees issued by governments, and especially by the preceding ones when governments change after an election. All lobbying has its source from that context. While in the US there are more person-toperson contacts (and hence more personal conflicts), the lobbying scenario in Europe is characterized by collective action through business affiliations and associations. Both ways might end up in people occupying a dual role in business and politics at the same time, and if handled professionally, that role could benefit both constituencies. All this is pretty much legal all across Europe and the US,

${ }^{83}$ Seattle Post, Nov. 16, 2007

${ }^{84}$ Treviño and Nelson 2004

85 Time Magazine of December 22, 2002, naming the Enron and WorldCom whistleblowers "Persons of the Year." although some of it may be in the gray area of business ethics. For that, NGOs and other watchdogs should be included in data sharing and reports. If these checks and balances are not in place, business will be lead to buy an influence on regulation, from "state capture" to outright corruption. Again, there are many means to combat corruption, starting with the UN Convention against Corruption and reaching to national and private institutions like the UK Fraud Advisory Panel, the "Bribe Payers Index", Transparency International etc., all supported by broad data interchange.

One subject that has many shades of "gray" is tax evasion. For the sake of conciseness, it will not be covered here.

\section{Leadership}

This comparison of how business conditions and values are generated spread and modified within different business environments would not be complete without some considerations on leadership. Can leadership produce values? Or better said, can it just secure that values are observed and adhered to when making decisions?

U.S. leaders are often reproached for being "ethnocentric" and biased to assume their value system is best $^{86}$. On the other hand, European leaders will often try to avoid uncertainties related with leadership change by "depersonalizing" management. They will establish a set of "substitute variables"87 such as high professional orientation, high coherence within teams, intrinsically satisfying tasks of subordinates, etc., to eliminate "adverse: effects of leadership change. At the same time, the subordinates will set up their own "substitute variables." As changes of leaders take place rather often on the international scene when expatriates are assigned and re-assigned to foreign subsidiaries, the international manager must learn how to cope with such "substitute variables" ${ }^{\prime 88}$. A topical study has shown ${ }^{89}$ that at least the functional flexibility is higher in U.S. management. Thus, U.S. managers might easier

\footnotetext{
${ }^{86}$ Hofstede 2000

${ }^{87}$ Yukl 1994

${ }^{88}$ Harzing 1999, Petersen 1993

${ }^{89}$ Hewitt-Dundas 1997
} 
find effective solutions to (functional) conflicts in multicultural environments ${ }^{90}$.

Other recent research has ascertained that American leaders are not as individualistic as has often been suggested $^{91}$. It has been shown that U.S. businesses are highly characterized by an egalitarian commitment ${ }^{92} 93$ even though they mostly have a command and control orientation with a top-down management approach. While this orientation may promote the view that employees may be used instrumentally towards the objective of the organization's executive to "create wealth," it is the conceptualization of 'egalitarian commitment,' the wide-spread endeavors of cross-cultural training and an increasing U.S. engagement in transition economies which have modified and 'softened' American instrumentalism.

The positive picture of US leadership traits has been radically changed by the Enron catastrophe, coupled with the simultaneous scandals at Worldcom, Tyco, to name a few. This has served to radically change public and business expectations of corporate accountability and the ethics of the corporate leaders $^{94,95,96}$. For many years the CEOs of the U.S. when compared to their European counterparts made dramatically more in compensation and earnings. Throughout the 1990's, U.S. CEOs' executive packages soared, and many executives won guarantees of big rewards whether or not their businesses succeeded. In the early part of this decade, European CEOs started to demand greater salaries and compensation packages. However, recent ethical scandals on both sides of the Atlantic as well as the financial crisis have lead to public outcry against CEO salaries. For example, the chief executive of a Standard \& Poor's 500 company made, on average, $\$ 14.2$ million in total compensation in 2007, according to preliminary data from The Corporate Library ${ }^{97}$. However, this type of executive compensation has become unacceptable as the public became aware of the large severance packages given to

\footnotetext{
${ }^{90}$ Ravlin, Thomas and Ilsev 2000

${ }^{91}$ Bond 2002

${ }^{92}$ Schwartz 1994

${ }^{93}$ Smith et al. 1996

${ }^{94}$ Hasson 2002

${ }^{95}$ Roberts 2002

${ }^{96}$ Verschoor 2006

${ }^{97}$ www.aflcio.org/corporatewatch/paywatch
}

CEOs of companies at the center of the mortgage crisis.

\section{Summary and Implications}

Although there are organizational and philosophical differences in how U.S. and European CEO's regard governance and ethics, it is imperative that business leaders on both sides of the Atlantic adhere to a code of ethics, and be pragmatic in their management practices and decision-making, especially in light of the current challenges in our financial markets. Ethical issues in business require norms that may very well be based on rational arguments, but their specific content must be generated from reallife experiences rather than belief systems. This argumentation of Discourse Ethics, as we have seen from the example of Social Accounting standards turns out to be a powerful principle: It is all about stakeholder engagement, which is the core of all social standards. ("A norm is valid when its foreseeable consequences ... could be jointly accepted by all concerned without coercion", and "Only those norms can claim validity that could meet with the acceptance of all concerned in practical discourse". ${ }^{98}$ Thus, the dilemma of weighing ethics versus effectiveness on an individual level becomes resolved because it is moved up to a communal level where the criteria for decision-making are contributed through interaction. And with this we can very well find a pathway (not far from Adam Smith's, but probably the other way round) from "Homo Oeconomicus" to "Homo Reciprocans" to "Homo Moralis" ${ }^{\prime \prime 99}$ For the practitioner, this explains why "Good Ethics" means "Good Governance" and also "Good Cost Control" through minimizing risks, avoiding fines, court-imposed remedies and criminal charges, reducing operational costs by properly handling environmental and workplace issues, avoiding loss of business and enjoying a greater access to capital $^{100}$ : Business ethics is the challenge of ensuring that the enormous entrepreneurial energies released by today's free-market global economy end up by serving society and not destroying it.

Ethics, as stated by Kent Druyvesteyn, who was vice president for ethics at General Dynamics from 1985 to 1993 and one of the first ethics officers in an

\footnotetext{
${ }^{98}$ Habermas 1999

${ }^{99}$ Lenz 2008

${ }^{100}$ Mitchell 2003
} 
American company, is "about conduct, from moral awareness to moral judgment to ethical decision making, and not about philosophy"101. But many executives, today, for good reasons, are also embracing the main theoretical foundations as this enlightens awareness and judgment. One proof of this would be the highly positive acceptance and the wide spread of the English version of Peter Ulrich's book "Integrative Economic Ethics"102 in the US. Ulrich, the leading German-speaking writer on the subject (the book is in its fourth edition in the original German version), progresses through a series of rational and philosophical arguments to address foundational issues and moving business ethics into the realms of political theory and civic rationality. No business leader will be able to neglect Ulrich's argument that corporations exist to serve human demands, and that human' demands are formed by society. So businesses will have to adopt a conduct to serve this principle.

\section{References}

AccountAbility 1000 (http://www. accountability21.net): $A A 1000$ AccountAbility Principles Standard 2008

AMA (American Marketing Association) Statement of Ethics 2004, retrievable from http://www.marketingpower.com

Benhabib, S., The Rights of Others: Aliens, Residents, and Citizens. Cambridge University Press, 2004.

Bond, Michael Harris, et al., "Social Axioms. The Search for Universal Dimensions of General Beliefs About How the World Functions". In: Journal of Cross-Cultural Psychology, 2002 (33), pp. $286 \mathrm{ff}$.

Brenkert, George G.: Marketing Ethics. Blackwell Publishing 2008.

Business Week, "Special Report: White-Collar Crime: Who does the Time?" February 6, 2006.

Crane, Andrew, and Dirk Matten: Business Ethics A European Perspective. Oxford 2004.

Denzin, N.K. and K. Erikson: "On the Ethics of Disguised Observation: An Exchange. In: Martin Bulmer (ed.): Social Research Ethics, pp. 142 151. New York 1982

\footnotetext{
${ }^{101}$ Sims 2003

102 Ulrich 2008
}

Di Norica, V.: The Knowledge Economy and Moral Community. In: Journal of Business Ethics 2002 (Vol. 38), pp. 167-177.

EMC (European Marketing Confederation). Code of Conduct, issued Februry 2005; retrievable from www.emc.be/codeconduct.cfm

Ferrell, O.C., J. Fraedrich and L. Ferrell: Business Ethics. Ethical Decision Making and Cases. $7^{\text {th }}$. ed., Boston - New York 2006.

Financial Times, 31. Aug. 2001: "P\&G admits spying on Unilever".

Fukuyama, Y. F.: Trust. The Social Virtues and the Creation of Prosperity. London 1995.

Gibson, K: Ethics and Business. An Introduction. Cambridge University Press 2007.

Gow, D.: Siemens chairman appeals for leniency from US authorities over bribery scandal. The Guardian, Jan. 24, 2007. (www. guardian.co.uk/business/2008/jan/24/eur ope - 56k).

Haase, Michaela: "Theory, Practice and Education On the Role of Business Ethics for Management Education at Business Schools or Universities". In: Cowton, Christopher, and Michaela Haase (eds.): Trends in Business and Economic Ethics. Heidelberg 2008, pp. $229-261$.

Habermas, J.: The Inclusion of the Other. Studies in Political Theory. Cambridge, MA, 1999.

Harzing, Anne-Wil K., "Managing the Multinationals. An International Study of Control Mechanisms". Edward Elgar 1999.

Hasson, J., "Telecom troubles." In: Federal Computer Week. 16(29), 2002, p. 20-24

Hayek, F. A. von, "The Road to Serfdom" University of Chicago Press, 1994.

HBR (Harvard Business Review): Harvard Business Review on Corporate Ethics, 2003.

Hefendehl, R: Corporate Criminal Liability. Model Penal Code Section 2.07 and the Development in Western Legal Systems. http:www. wings.buffalo.edu/law/bclc/bclrarticles/4(1)/hefe hndehlpdf.pdf.

Hewitt-Dundas, Nola, "Corporate Flexibility. A Comparative Analysis of Small Firms in Northern Ireland and Massachusetts". Avebury, 1997.

Hofstede, Geert, "Whatever Happened to Masculinity and Femininity?" In: Cross-Cultural Psychology Bulletin, 2000 (34), No. 4, pp. 14- 19.

IBM (www.ibm.com): Big Blue Goes Green (http://Www.ibm.com/systems/virtualization/vie w/071807.html) 
Kotler, Philip: Marketing Management. The Millennium Edition. Prentice Hall 2000.

Lenz, Hansrudi: "Why Act Morally? Economic and Philosophical Reasons". In: Cowton, Christopher, and Michaela Haase (eds.): Trends in Business and Economic Ethics. Heidelberg 2008, pp. 131 $-152$.

Melloan, George, "Europe's Printemps of Discontent". In: The Wall Street Journal, May 31, 2005.

Mitchell, Charles: International Business Ethics. Combining Ethics and Profits in Global Business. World Trade Press 2003.

MRS (Market Research Society) Code of Conduct (http://www.mrs.org.uk/standards/codeconduct. $\underline{\mathrm{htm})}$

OECD (Organization for Economic Cooperation and Development): Economic Outlook No.79, June 2006, Annex table 25.

Palmeri, C., "Guilty Verdicts for Enron Staff," Business Week, May 25, 2006.

Peterson, Richard B., ed., "Managers and National Culture". A Global Perspective. Quorum Books 1993. PR Newswire, "CED Releases Recommendations for Improving Corporate Governance," New York, March 21, 2006.

Preuss, L.: "In dirty chains? Purchasing and greener manufacturing". In: Journal of Business Ethics, Vol. 34 (2001), pp. 345 - 359.

Ravlin, Elisabeth C., David C. Thomas and Arzu Ilsev, "Beliefs about Values, Status, and Legitimacy in Multicultural Groups - Influences on Intragroup Conflict." In: P. Christopher Early and Harbir Singh (eds.), "Innovations in International and Cross-Cultural Management". Sage, 2000.

Rawls, John, "Political Liberalism", Columbia University Press, 1993.

Roberts, R., "Ethics and corporate responsibility following Enron." A presentation to the 2002 annual fall compliance conference: Risk Management for the Real World! Sponsored by National Regulatory Service, September 12, La Jolla, Ca.

Sarbanes-Oxley Act of 2002. 10 ${ }^{\text {th }}$ Congress, Public Law 107-204, July 30, 2002.

Schwartz, S. H., "Beyond Individualism and Collectivism. New Cultural Dimensions of Values". In: U. Kim, H.C. Triandis et al. (eds.): "Individualism and collectivism. Theory, method and application". Sage 1994.
Seattle Post, Nov. 16, 2007: "Boeing bosses spy on workers"; retrievable from http://seattlepi.nwsource.com/business/339881 boeingsurveillance16.html.

Sims, Ronald R.,: Ethics and Corporate Social Responsibility: Why Giants Fall. Westport 2003.

Smith, P. B. et al., "National culture and managerial values. A dimensional analysis across 43 nations". In: Journal of Cross-Cultural Psychology, 1996 (27), pp. $231-264$.

SAI (Social Accountability International): Social Accountability Standard SA 8000, updated 2002.

The Daily Telegraph, 02. Aug. 2001:" Suddens quits as chief of Wm Baird".

The Independent, 1. Oct. 2002: "Echostar begins piracy lawsuit against NDS".

Time Magazine, Dec 22, 2002: "Persons of the Year".

Treviño, Linda K., and Katherina A. Nelson: Managing Business Ethics. Straight Talk about How to Do It Right. $3^{\text {rd }}$ ed., John Wiley \& Sons 2004.

Ulrich, Peter: Integrative Economic Ethics. Foundations of a Civilized Market Economy. Cambridge University Press, 2008.

Verschoor, Curtis, "Tyco: An Ethical Metamorphosis". In: Strategic Finance, April 2006, Vol.87(10), pp15-16.

Web-Services:

wWw.consumerfraudreporting.org

www.corporateregister.com

www.globalreporting.org

Website Sources:

www.aflcio.org/corporatewatch/paywatch: "2008 Executive PayWatch"

www. boingboing.net/2006/07/05/coke-employeesbuste.htm/:" "Coke employees busted for trying to sell formula to Pepsi"

www. unwiredview.com/2008/05/26/deutschetelekom-admits-to-spying

Yukl, Gary A., "Leadership in Organizations". 3rd ed., Prentice Hall, 1994. 